\title{
Hungry gazes, digesting closeups: Pasolini, 'Porcile' and the politics of consumption
}

Article

Accepted Version

Elduque, A. (2017) Hungry gazes, digesting closeups:

Pasolini, 'Porcile' and the politics of consumption. Screen, 58 (2). pp. 119-140. ISSN 1460-2474 doi:

https://doi.org/10.1093/screen/hjx014 Available at https://centaur.reading.ac.uk/82227/

It is advisable to refer to the publisher's version if you intend to cite from the work. See Guidance on citing.

To link to this article DOI: http://dx.doi.org/10.1093/screen/hjx014

Publisher: Oxford University Press

All outputs in CentAUR are protected by Intellectual Property Rights law, including copyright law. Copyright and IPR is retained by the creators or other copyright holders. Terms and conditions for use of this material are defined in the End User Agreement.

www.reading.ac.uk/centaur

\section{CentAUR}


Central Archive at the University of Reading

Reading's research outputs online 


\title{
From Hunger to Digestion: Gazes, Faces and Pigs in Pasolini's Porcile
}

\begin{abstract}
In the late sixties and early seventies, European political cinema showed great interest in the topic of consumption, either in films about the bourgeoisie or in stories on anthropophagy. In movies by Marco Ferreri, Liliana Cavani and Jean-Luc Godard, ingestion was used both as a metaphor for consumer society and as a concept to help the spectator rethink his relation with the film. Pier Paolo Pasolini was a central figure in this context, and his film Porcile/Pigsty (1969) played a key role in it, as it proposed numerous links between consumption and consumerism, both in the relationships between the characters and between the two stories that shape the film. In this article, I intend to analyse the film from the point of view of its visual consumption, focusing on the editing links between images and the spectator's visual consumption. Using Pasolini's texts (both the theoretical ones and opinion articles), as well as some analysis on avant-garde art, particularly on works by Jacques-André Boiffard and Georges Grosz, we explore the concepts of hunger, consumption and digestion as aesthetical and analytical dispositifs to study images. The visual analysis results in three narrative and editing characteristics: the hungry gaze, the swallowing close-up and the plastica facciale. They appear as specific concepts of the film, but they can also be used to examine other movies, as well as to rethink film language in general.
\end{abstract}


In his last interview, held on the occasion of the French release of his film Salò o le 120 giornate di Sodoma/Salò, or the 120 Days of Sodom (1975), Pier Paolo Pasolini was asked if cannibalism was political. He answered that it was a political fact that was real in certain contexts and metaphorical in others. In answer to the next question - whether cannibalism was the best way to free oneself of political enemies - he replied with two modest proposals, in the style of Jonathan Swift: to devour school teachers and to devour the directors of Italian television. It was a provocative answer to a provocative question, and a significant closure to a public trajectory and an œuvre where consumption had played a key metaphorical role: while Pasolini the public man wrote about the consumer society and defined it as a new fascism, he filmed movies where ingesting potatoes, sharing of raven or eating another human had a narrative relevance. The two actions weren't disconnected: during his career, he made numerous rich reflections on the links between consumerism and consumption. In this text I will focus on the most important one: his feature film Porcile/Pigsty (1969).

\section{Around the pigsty}

The case and film of Pasolini were by no means isolated. In the European political cinema of the late sixties and early seventies, many movies used the concept of consumption, either as a metaphor for the consumer society or as a radical opposition to it. One key film is La grande bouffelThe Big Feast (1973), featuring four liberal professionals who celebrate a gastronomic seminar while hungry dogs are dying outside the house; such an opposition has been interpreted as a conflict between rich Europe and the Third World ${ }^{\mathrm{i}}$. Although it has been stated that the film cannot be reduced to the narrow and stifling limitations of allegory ${ }^{\mathrm{ii}}$, the opposition between a consumerist Europe and a hungry Third World seems a feasible interpretation, considering that other films by Ferreri from the same period dealt with consumerism (Dillinger è morto/Dillinger Is Dead [1969] and Il seme dell'uomo/The Seed of Man [1969]) and colonisation (Touche pas à la femme blanche/Don't Touch the White Woman! [1974]). According to this idea, La grande bouffe depicts a complex contemporary phenomenon through abstraction: these men are isolated from everything else, and we don't know why they want to eat till they die. The only thing that is certain is consumption; that's the main focus of the film, though it's accompanied by related actions, such as sexual acts, vomiting and defecation. 
In this context, the mythical figure of the cannibal was recovered as a radical opposition to consumption/consumerist society, an opposition which is precisely carried out through wild consumption. That's the case with the barbarian Colchis in Medea (Pier Paolo Pasolini, 1969), the clandestine couple in I cannibali/The Cannibals (Liliana Cavani, 1970) or the blue-collar worker in Themroc (Claude Faraldo, 1973), who throws away all his purchased objects and creates a small cannibal commune with his neighbours; in Week End/Weekend (Jean-Luc Godard, 1967), a particular variation is proposed, as the guerrilla who seems to represent a radical opposition to consumerist society becomes finally a wild deformation of $\mathrm{it}^{\mathrm{iii}}$. In fact, at that time cannibals invaded auteur film: Fellini used them in Fellini-Satyricon/Satyricon (1969) and even Antonioni had worked on this topic in his project Tecnicamente dolce, although it was never brought to fruition ${ }^{\text {iv }}$; the Third World cinema, with features such as Macunaíma/Macunaima (Joaquim Pedro de Andrade, 1969), served to reinforce interest in anthropophagy as a radical political reaction and as a metaphor of consumerist society. In fact, prior to Cannibal Holocaust (Ruggero Deodato, 1980) and other Italian exploitation films, in the late sixties and early seventies, anthropophagy possessed a relevance not only in cinema, but also in other disciplines: for instance, in 1972 the journal Nouvelle Revue de Psychanalyse approached the topic from both an anthropological and a psychoanalytical point of view in the monographic issue Destins du cannibalisme ${ }^{v}$.

In addition, all these films appeared as emblems of a cinema which questioned the spectator's visual consumption through radical narrative strategies: in Themroc, the characters don't talk, they just growl and shout, while the stranger played by Pierre Clémenti in I cannibali speaks an unknown language; in La grande bouffe, and in all the movies by Ferreri at that time, the narrative impasse and the Kafkaesque circularity gain importance over linear classical narrative, or even the joyful liberty of the first films of modern cinema (the ones by the Nouvelle Vague, for instance). Pasolini radicalised film's transgression of beauty in Salò o le 120 giornate di Sodoma, a film that also speaks, metaphorically, of the aggressive ingestion of both bodies and their images. Filmmakers themselves recognised this approach to the spectator's visual consumption: Ferreri said that he wanted to make physiological films ${ }^{\mathrm{vi}}$, while Pasolini, who was very critical of consumer society in his articles, reacted against it in his films, by seeking an hermetic 
language that couldn't be assimilated by consumer society; that is, an art that was impossible to consume ${ }^{\text {vii }}$.

Pasolini, in fact, is a central figure in this context. He said that his first cinema-related memory was an advertising brochure in which a tiger ate an explorer: he discovered it as a child and it awakened erotic passions in him ${ }^{\text {viii }}$. The rationale of consumption was a major metaphor in his analysis of consumer society, where, he believed, the main fear and greatest desire of the individual is to be devoured ${ }^{\mathrm{ix}}$. But his role as an intellectual didn't elude either this context or an ambivalent attitude to it: this is why his public selfexposure, either in articles or interviews, has been analysed using the metaphor of the animal sacrifice ${ }^{\mathrm{x}}$. For him, consumption was the primordial concept of repressive modern societies, but also, as we have seen at the beginning of this text, the most suitable reaction to it. Probably for this reason his cinema is full of human relations built on voraciousness and swallowing: the imitation of the Metro-Goldwyn-Mayer's lion as a metaphor for a pimp at the beginning of Accattone (1961), the impulsive and accelerated ingestion in La ricotta/Curd Cheese (1963), the sharing of the crow at the end of Uccellacci $e$ uccellini/Hawks and Sparrows (1966), and the excrements and nails served in Salò o le 120 giornate di Sodoma.

Porcile is probably his most explicit film on the dynamics of consumerism/consumption, and it is, along with Week End, the most important European movie of this tendency. In it, all the relations between the characters are built upon the idea of consumption, through two separate stories which are intercalated. In the first one, which takes place in Sicily in the $15^{\text {th }}$ century, a hungry man (Pierre Clémenti) searches for food near the desert slopes of Etna volcano and ends up becoming a cannibal. As he goes on, he meets different people who join him, but they are finally trapped by the city government and condemned to be eaten by wild dogs. Meanwhile, the second story is set at the time the movie was made, in the late sixties. Here, a powerful industrial businessman, Mr. Klotz (Alberto Lionello), seeks to defeat another businessman, Mr. Herdhitze (Ugo Tognazzi), using the latter's Nazi past to blackmail him. Meanwhile, Mr. Klotz's son, Julian (Jean-Pierre Léaud), is the boyfriend of a young left-wing activist, Ida (Anne Wiazemsky); but it's a failed relationship, as he is unable to have sex with her because he has a terrible secret, and ends up suffering paralysis. When Klotz meets Herdhitze to blackmail him, Herdhitze blackmails Klotz as well, as he has discovered Julian's secret: he likes to fornicate with 
pigs. At the end of the film, Klotz and Herdhitze merge their enterprises and Julian, who has overcome his paralysis, is devoured by the pigs.

From a production point of view, and particularly in its casting, Porcile/Pigsty works as a compass point for the majority of consumption/consumerism films of that time. It brings together Jean-Pierre Léaud and Anne Wiazemsky, two of the main performers in Godard's militant film La chinoise (1967), prior to Week End; Pierre Clémenti, who would later work in I cannibali; Marco Ferreri, the future director of La grande bouffe, who had worked with cannibalism as a metaphor for human relationships ( $L$ 'ape regina/Queen Bee [1963] and La donna scimmia/The Ape Woman [1964]) and would made it more explicit in later films (Ya bon les blancs/How Good the Whites Are [1988] and La carne/The Flesh [1991]), and Ugo Tognazzi, Ferreri's favourite actor and one of the performers in La grande bouffe. Thematically, Porcile displays a wide range of consumption relationships: the cannibals eat people, but they are finally eaten by dogs; Herdhitze ate Jews in his Nazi past, and now Mr. Klotz wants to eat his enterprise, and they merge their businesses while Julian is devoured by pigs. Pasolini said that cannibalism was a symbol of extreme rebellion ${ }^{\mathrm{xi}}$ (something that can clearly be seen in the episode set in the past), but anthropophagy is also a metaphor of consumer society, as depicted by the characters of Klotz and Herdhitze, who constantly talk about eating and digestion. These two parts, the old and the new, the barbaric and the civilised, are alternated and compared, so as to generate a discourse, though the possible relations between them are multiple and the real meanings remain uncertain. Finally, Porcile is similar to other films at that time in its radical approach to language: the part set in the past is completely mute, except for the reading of the cannibal's sentence, which is drowned out by the noise of bells, and the words Pierre Clémenti says before dying, which Jean-Michel Gardair considered to be the birth of language because of their isolation ${ }^{\text {xii }}$. Meanwhile, the modern-day story is all spoken and has hardly any action, just lengthy, verbose dialogues.

In Porcile, consumerism/consumption is presented as a clear thematic opposition, and Pasolini's desire to create a film that is impossible to consume is expressed in its radical use of language - both its absence and its excess. However, I believe that these two ideas (consumption as a topic and visual consumption of the film) remain separated, one on the level of the theme and the other in the spectator's experience, and the link between them 
can be analysed deeper. In this text I intend to explore the relation between the consumption of the characters and that of the spectator, focusing on how they consume and how it is shown through cinematic procedures. To do so, I will start with a particular moment in the film, made up of three shots (Figure 1). When the cannibals have created a small anthropophagus community and they are perceived as a risk by the people in the city, the government decides to set them a trap: two young bodies, a man and a woman, which are shown naked in the middle of nothingness. After a few contextual images, we see a close-up of Pierre Clémenti looking into the distance, and slightly opening his mouth; just afterwards, we see his subjective view, with a noticeable zoom towards the bodies that have been offered. Once we have reached them, Pasolini cuts to a close-up of Herdhitze, the industrial rival of Mr. Klotz. The camera lingers several seconds on him.

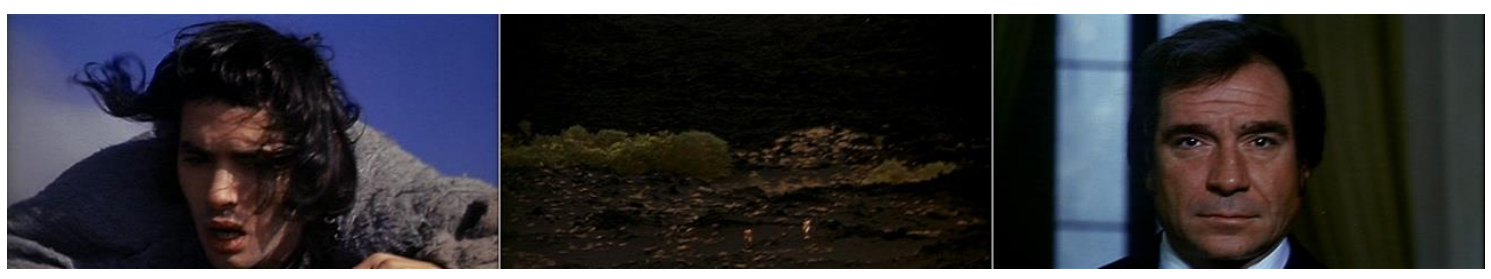

Figure 1

The basis of my work will be these three shots: the face of the cannibal, the approach shot to the naked bodies and the face of the businessman. My thesis is that this three-part chain contains the main ideas of consumption/consumerism in the film. The combination between the first and the second implies hunger; while the change from the second to the third signifies consumption; and the time the camera remains on this last shot brings us to digestion. I will approach the first two using Pasolini's film theory and the analysis of avant-garde images by Georges Didi-Huberman and María Cunillera, and the third one by following a comparison with George Grosz's works. However, the main source for the text will be the movie itself, with its own images and dialogues.

\section{The hungry gaze}

Regarding the film as food is not a really new idea: analogies between flesh and the visual can be traced back to art from centuries ago, a good example being Mieke Bal's analysis of the two versions of Rembrandt's Slaughtered Ox $x^{\text {xiii }}$. However, it's in the 1920s when 
they became usual, particularly in avant-garde art. This period is rich in alignments of flesh and images through the cut, which is both real and visual, like in the slaughter of the bulls in Stachka/Strike (Sergei M. Eisenstein, 1925) and the sliced eye in Un chien andalou (Luis Buñuel, 1929). Georges Didi-Huberman's analysis of Georges Bataille’s magazine Documents presents some similar analogies: in a chapter entitled "La découpe dans l'anthropomorphisme" ("The cut in anthropomorphism"), he compares two images that appeared in the same issue, but on different pages: the photos by Eli Lotar of a row of cut animal legs in La Villette's slaughterhouse, and the line of sensual, dancing legs from the Hollywood film Fox Movietone Follies of 1929 (David Butler, 1929). Between them he establishes some analogies: cut bodies and framed bodies, flesh to eat and flesh to watch, cut-sacrifice and cut-artifice, butcher's table and shopping window, etc. ${ }^{\text {xiv }}$

Pasolini sometimes presented striking images (the ritual sacrifices in Medea, the torture scenes in Salò o le 120 giornate di Sodoma), while characters in Porcile mention Brecht and Grosz, but in general he wasn't much influenced by the 1920s avant-garde movements. However, he also worked with these dialectics between consumption and the visual in both his films and his theoretical articles. It is in the latter that we can find the first hints of his voracious approach to cinema. In the previous sentences to his text "Res sunt nomina" he characterises the camera as a reality-eater ("Mangiarealtà") and an eyemouth ("Occhio-Boca"), and stresses its hunting nature by emphasising its name in Italian ("macchina da presa" - "capture machine") ${ }^{\mathrm{xv}}$. That is an idea he returns to in the last chapter of his volume Empirismo eretico, where he uses the image of a barbarian hunting an animal as a multifaceted example to list different codes of reality: lived reality, observed reality, imagined reality, represented reality, evoked reality, described reality, photographed reality, transmitted reality and reproduced reality ${ }^{\mathrm{xvi}}$. Regarding these two textual examples, Marco Antonio Bazzocchi identifies the primitive man with the realityeating camera, and his ingestion of food with the visual procedure of filming the world ${ }^{\mathrm{xvii}}$. He is obviously thinking of the cannibal played by Clémenti.

In fact, we hardly ever see this cannibal eating: he finds, hunts and eats a butterfly, a snake and a soldier, but most of the time the film shows him in long shots walking, wandering, looking for food on the slopes of Etna, but not eating. His gaze searches for things to catch and consume, just like a film camera, an eye-mouth, which films the world so as to give it to the spectator. In all these moments, the cannibal's hungry gaze and the 
way the spectator watches the film are aligned: both are faced with an empty space and both are looking for something, either to eat or to watch: the butterfly, the snake and the soldier are real food for the cannibal and visual food for the spectator. Although the story is geographically and historically situated (Sicily in the $15^{\text {th }}$ century, under Spanish domination), this landscape has been defined by critics as a primordial and ahistorical place $^{\text {xviii }}$, and this reinforces its metaphorical nature as a cradle where new images can be born. That is an obvious common feature with Luis Buñuel's film Simón del desierto/Simon of the Desert (1965), which had a key role in the genealogical process of Porcile: initially, the cannibal's story was supposed to be a second episode to be screened after Buñuel's film. The cannibal and Simón are, in fact, very similar: both are hungry and gaze off into the desert waiting for something to appear, either real or imaginary, and both are finally transformed into objects to be metaphorically consumed by the community.

These images that appear in the desert have both narrative and aesthetic implications. Let's start with the narrative ones. In the book Pierpaolo Pasolini: corpi e luoghi, Michele Mancini and Giuseppe Perrella devote a whole chapter to images of food in Pasolini's cinema. In the introduction to it, they state that Pasolini isn't much interested in the miseen-scène of the food, but in the relations it establishes with characters: their proximity to, or distance from food makes the characters move, so it becomes a major motor of action in films and it's even possible to speak of food as a story ${ }^{\mathrm{xix}}$. That happens in many Pasolini films, from the erratic developments in Accattone to the Chaplinesque gags of Ninetto Davoli in I racconti di Canterbury/The Canterbury Tales (1972). Mancini and Perrella add that in La ricotta, the tables of the main character are never stable places, but dispersed and hidden ones. In the case of Porcile's cannibal we have a radical example of it: the motor of hunger is the only motivation for the character's movement (without any kind of psychological or social explanation, as happens in the previous examples), while the dispersed tables (the hunting situations) are the only narrative key points in his story. This sobriety characterises not only the first sequences, where he is walking alone, but also the later chapters, when he finds other people and forms a little cannibal community: till they are trapped, maybe the only action that goes beyond the simple need to eat is the rape of some women by his partner, played by Franco Citti. Apart from this, the narrative only advances when a new hunting object appears. The dualism hunger/consumption, thus, shapes the narrative development: the absence of food is also 
the absence of plot and absence of image; when it appears, it makes the story continue and gives the spectator something to see. After the consumption, both real and visual, the eaten object fades away and the story becomes empty again.

Moreover, the moment in a film when food appears also has aesthetic implications, which can be examined using Pasolini's theories on editing. In 1966, the filmmaker explained to Adriano Aprà that his conception of cinema was determined by his love to reality. In his view, this love implied two different cinematographic techniques: first, in linguistic terms it led to the long take: an infinite and continuous sequence shot that is the basis of cinema, as it offers a fluent and uninterrupted reproduction of reality; second, in expressive terms, this love to reality resulted in editing, as Pasolini's camera focuses on something (a face, an object or a landscape) in order to violently sacralise or desacralize it. Following this opposition, Pasolini differentiates between the analytic linearity of cinema as a long take and the synthetic linearity of the edited film, where reality isn't simply reproduced, it is also organised through the articulation of different shots ${ }^{\mathrm{xx}}$. Pasolini went on to explore these ideas in greater depth in his subsequent text, "Osservazioni sul piano-sequenza", where he associated editing with human death, as both give a sense to the reality they are part of (the film and human life, respectively) ${ }^{\mathrm{xxi}}$. Editing, thus, is regarded by him as a consequence of desire and a synonym of death.

Just like Pasolini, the cannibal in Porcile selects a certain reality and frames it. He is driven by a desire which is both nutritive and sexual ${ }^{\mathrm{xxii}}$, and the consequence of this is the death of what he focuses on. His walks in the desert are shown through different images, but they are potentially just one: a sequence shot that is infinite, just like his hunger. At a secondary level, this continuity in image and hunger is interrupted by the arrival of the butterfly, the snake and the soldier, which are framed separately. In this way, the dialogue between hunger and consumption is here a dialogue between a potentially infinite sequence shot of the hungry man and the sudden manifestation of a new image of food. Just as at a narrative level the hunger motor leads to the emergence of a nutritive key point, from an aesthetic point of view the waiting of a single image corresponded with a new frame arising from violence and desire, a frame which is hunted by the gazes of both the cannibal and the spectator. 
Editing is, thus, a strategy of hunting through the framing of the desired object. That is the way to isolate it from its context, but sometimes it's not enough, and it's necessary to select a certain part of the victim. That is the case with Pasolini, for whom the desire not only searches for certain bodies, but also for certain parts: he isolates a face, an arm, a leg or genitals to sacralise or desacralize them. In the case of Porcile, this fragmentation is aligned with the diegetic fragmentation of human body, particularly when the cannibal is eating his first victim and the camera shows us separate parts of the body: first the foot, then the hand. In fact, Sam Rohdie says that for Pasolini cutting bodies with editing was an erotic and sadistic pleasure, and compares his attitude to that of the cannibal in this film, whose only words refer to the shiver of pleasure he feels when eating human

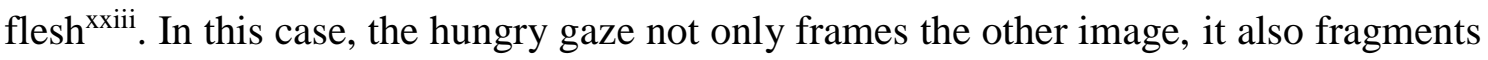
it in different parts to make his consumption and our own easier.

The zoom image we mentioned at the beginning doesn't contain body fragmentation, but it's a clear example of the hungry gaze: the face of hunger (Clémenti) leads us to the image to be consumed (the bodies), and the approximation to it is done by means of a lens movement. In this second image the gaze itself becomes, literally, a motor of hunger, looking for something to eat and to see, just as if the zoom was a nibble which suddenly dove into the world. The hunger of the cannibal and that of the spectator, thus, seek out new images, cut them and make the film move. They desire the movie, so they shape reality to get it.

\section{The swallowing close-up}

As we have seen, the part of Porcile that is set in the past includes violent scenes of hunting, fighting or eating which can be aligned with certain visual procedures, particularly framing and body fragmentation. While the cannibal played by Pierre Clémenti attacks his reality to obtain food, Pasolini's camera swallows and transforms the world to build a certain visual language. In this section, thus, this parallelism is possible. On the contrary, the contemporary story is characterised by the absence of any visual explicitness: most of the scenes occur in Mr. Klotz's neoclassical villa and are shaped by long dialogues with each character standing rigidly in front of the other. However, violence doesn't disappear at all. It is concentrated in these chatty discourses, 
as the characters talk about sex, ingestion, voraciousness and digestion, focusing on two major topics: the distorted sexuality of Julian, who fornicates with pigs, and the history of Germany, a country that, as they say, has a great capacity to digest the past, particularly the killing of millions of people in concentration camps. For this reason the close-up has a special importance: in an article devoted to the face in Teorema/Theorem (Pier Paolo Pasolini, 1968) and Porcile, Anna Gilardelli counts the number of close-ups in these films; in Porcile she detects 474 close-ups and large close-ups, including 30 medium close shots and 26 object shots; as there are 751 shots in the movie, the close-ups represent $63.1 \%$ of the total amount. Although her selection criteria seem to be a bit loose, the analysis is significant anyway: the close-up has a major role in Porcile.

In this context, the close-up that shows Herdhitze, just after the image of the naked bodies, has a special importance. The character has been mentioned before in the talk between Mr. Klotz and Hans Günther (Marco Ferreri): they say that in the past Herdhitze was a professor of anatomy in Strasbourg University and his name was Hirt; at that time, he requested that the Nazis give him huge quantities of craniums of Jew communist commissioners, which came directly from the death camps. Today, he has changed both his name and his face, thanks to plastic surgery (plastica facciale), and has become a prosperous industrialist in West Germany. The verbal insistence in the term plastica facciale makes his presentation as a close-up logical. I will focus on it in the next section. For now, I would prefer to point out the relation between this image and the preceding one, the one with the naked bodies. These bodies, which at the diegetic level correspond to a trap to catch the cannibals, acquire a new meaning, juxtaposed with the face of Herdhitze: they are reminiscent of the naked bodies of the murdered Jews, whose craniums had been requested by Dr. Hirt from Strasbourg University. Regarding this editing juxtaposition of naked bodies and a Nazi face, and some dialogues on voraciousness in this part of the film, a striking question arises: although these two images belong to different temporal layers, is it possible to establish an ingestion-related link between them, as I did before with the cannibal and his victims? Can we find a voracious quality in the close-up?

Here we need to return to the 1920s' avant-garde to seize some new key concepts to examine the images in Porcile. In his study on Documents, Georges Didi-Huberman analyses the link between space and the eye: as he did with the idea of the cut that I 
explained before, here he achieves a new concept through the opposition of two images in the magazine. The first appeared as an illustration of the definition of "eye", and it's a Grandville drawing in which a chain of eyes turns into a piranha which chases a man and eats him. The second one, which accompanied the definition of "space", is the photograph of a big fish opening its mouth to swallow a smaller one. Following these two images, Didi-Huberman links gaze, space and voraciousness, and states that the voracious eye is a "spatial form of experience" associated with disproportion: there is an opposition between two identical forms (two fishes) where the bigger one devours the other ${ }^{\mathrm{xxiv}}$.

Didi-Huberman transfers this voracious relation through disproportion to the relation between spectator and images, and exemplifies it with the photographs of Jacques-André Boiffard. His images of fingers, toes, necks and mouths are framed as if they were faces, and they become portraits. In accordance with Didi-Huberman, compared to these enormous human heads, our own becomes little and we feel like the small fish in front of the big one: these images "make us open our eyes wide like a little fish in front of a big one, as if we were going to be devoured". Here disproportion establishes a voracious relationship between spectator and image which makes him feel cornered ${ }^{\mathrm{xxv}}$. This effect is reinforced by the disappearance of context: for Didi-Huberman, Boiffard's photographs are not details, but totalities, as they are capable of eating everything and exist by themselves $^{\mathrm{xxvi}}$; for María Cunillera, who comments on his analysis in a dissertation devoted to voraciousness and the visual in $20^{\text {th }}$ century art, the photographed opened mouth seems to have already eaten its own human figure, and these images, as they deny perspective, don't allow the spectator to gain any distance, so his space is invaded ${ }^{\mathrm{xxvii}}$. There's no freedom for the spectator when he approaches these photographs: there's a tyranny either of the toe or the mouth that doesn't allow him to move freely within the image.

The visual experiences analysed by Didi-Huberman and Cunillera are very similar to those created by the close-ups in the early years of cinema. As Pascal Bonitzer explains, at first they were perceived as large cut heads, membra disjecta separated from their bodies; this independence gave them a double role within the space of cinema: as they can destroy scales and hierarchies, they are revolutionary; as they aggress the homogeneity of bodies and impose their power on the spectator, they are terrorists ${ }^{\mathrm{xxviii}}$. In the big screen of cinema, then, the disproportion mechanism of the avant-garde close-up 
becomes even greater: the image is more isolated than in a painting or a magazine, as it is shown in a dark room; and the size difference with the public is multiplied, so the metaphor of the big fish (image) which eats the smaller one (the spectator) comes to make sense. In addition, film incorporates a new key dimension to these disproportionate images: their relation with time and their evanescent presence on the screen, each shot appearing one after another and disappearing to make way for a new one. For this reason, I think that disproportion must be studied in regard not only to the spectator, but also by editing relations between images. We have seen before that framing can be a synonym for hunting: a hungry face looks at something it desires, and the second image shows it to us. Now we can approach editing in the opposite direction: the appearance of the closeup menaces and devours not only the spectator in front of it, but also the preceding image.

In the late sixties and early seventies, some filmmakers tried to recover this violent nature of the close-up. Before returning to Porcile, we can find this concept in the abovementioned La grande bouffe, which Pasolini analysed in his text "Le ambigue forme della ritualità narrativa" and is considered a precedent of his last film, Salò o le 120 giornate di Sodoma ${ }^{\text {xxix }}$. The movie is mainly shaped by sophisticated images with a refined composition: in the elegant mansion, the actions are staged in different levels of depth thanks to the perspective built using a long table (the kitchen) and the spatial multiplicity achieved with mirrors (the Chinese room). Sometimes, the long shots in these settings are violently interrupted by huge close-ups of the characters, and the composed image is substituted by the organic imposition of the human face, just like in Boiffard's photographs. The voracious nature of these shots is strongly emphasised: many times these close-ups appear when the characters are eating (slurping on a marrow, biting a sausage or swallowing a kidney), and sometimes they are the last image of the sequence. These three characteristics (sudden appearance of the face, coincidence with the eating process, and closure of the sequence) allow me to propound a visual idea: what these close-ups eat are the respective images that preceded them. In this way, Ferreri's film proposes a similar mechanism to that of avant-garde images, but at the same time links it with the plot and with the editing relations between the images. That is a characteristic which can also be found in another of Ferreri's films, $L$ 'ape regina, where Marina Vlady's face seems to devour her husband and everything else: her head not only synthesises a sex act which ends up with the husband being carried into an ambulance, it also closes the film, after his death and the birth of their son. 
In accordance with avant-garde art, as well as in Marco Ferreri's films, I would claim that the close-up has a voracious nature not only against the spectator, but also against the image that precedes it: a big face can metaphorically eat the preceding shot. That is the opposite of the hungry gaze we've seen before: while in that instance the desire to eat made a second image to be framed, here the first image is devoured by the second one. Herdhitze's presentation in Porcile is a shining example of both: first, the cannibal wants to eat and his hungry gaze provokes the frame of the bodies and the zoom; second, Herdhitze has already eaten this same image, as these bodies are incarnations of those millions of cadavers in the extermination camps. In this example, the hungry gaze is followed by the swallowing close-up, and the same image (the bodies) is desired by a character (the cannibal) and has been already eaten by a second one (Herdhitze). Our spectator status also changes: first, we desire an image to eat, and we see it thanks to the zoom; afterwards, the imposing image of Herdhitze is presented before us, reducing our freedom to watch what we want, and making us feel like a little fish in front of an enormous one.

\section{The plastica facciale}

We've seen how the voracious gaze of the cannibal can go closer to the naked bodies and how the sudden appearance of Herdhitze's face on the screen creates the idea of consumption. In these two procedures, editing becomes a key mechanism to design eating relations between images, in one direction or another. Now I would like to focus on what happens after the sudden appearance of this close-up: before the scene begins, the camera lingers briefly on the face, while the character remains still and quiet. Here I don't plan to analyse an editing relation that can awaken our desire or make us feel menaced, but a subsequent reflexion on a single image: Herdhitze's face. After hunger and consumption, we arrive at digestion.

What do we see in Herdhitze's inexpressive face? The plastica facciale: the old university professor, a generous supplier of Jews' craniums to the Nazis, has undergone plastic surgery to start a new life as a wealthy businessman in capitalist West Germany. This is not a mere narrative excuse, but a central concept: the characters refer to it time and again, 
and it sums up the way bestiality and violence are assimilated into the bourgeois world one of the main ideas in the film. As we have heard about it before, when we see his face for the first time we just focus on it, scrutinizing his eyes, cheeks and mouth, and crucial questions arise. What is Herdhitze's real face? What is hidden beneath the plastica facciale? The expressionless Herdhitze doesn't seem to give any clue, but as spectators we remember the film's garrulous dialogues, and a key reference arises: the drawings of George Grosz. In our reflexive digestion as spectators, thinking about Herdhitze's digestion through plastica facciale, we will think about this close-up in comparison with the works of the Berlin artist.

"The times of Grosz and Brecht still haven't gone away", says Mr. Klotz to his wife, "I could have been depicted by Grosz in the form of a sad pig, and you in the form of a sad sow, at the table, of course. I would be with a secretary's backside on my knees and you would have your hands between the chauffeur's legs. And Brecht, may he rest in peace, could have given us the role of the baddies in a play where the poor people are the goodies." This reference to Grosz and Brecht not only establishes a link between presentday Germany and the Nazi one, which forced them to emigrate, it also clarifies a few aesthetical ideas in the film. Focusing on Grosz, we find an artist who examined hunger and consumption by regarding both its animal nature and its political implications, just as Pasolini did. That is clear in a 1922 drawing in which a fat bourgeois man hugs banknotes and coins on a table while a skeletal woman begs for money, and with the subtitle "Swim if you can, and if you are too weak, you go under" ("Schwimme wer schwimmen kann, und wer zu schwach ist gehe unter"), a quotation attributed to Schiller ${ }^{\mathrm{xxx}}$. In addition, Grosz was a caustic observer of bourgeois life in Germany between the wars. The eloquent title of his most well-known volume, The Face of the Ruling Class, seems to sum up what he sought: to draw the bourgeoisie and discover their voracious nature, showing them as if seen through $\mathrm{X}-$-ray $^{\mathrm{xxxi}}$, and allowing their animal nature to emerge. Throughout his works, Grosz drew businessmen, bourgeois and generals with the features of pigs, and not only in lascivious situations (as in the cabaret of "Call of the Wild"xxxii and the rendezvous with the prostitute in "Circe"xxxiii), but also in daily life.

Where is the pig in Pasolini's film? What lies beneath the plastica facciale? What is the face of the ruling class here? Different answers are possible. One is that we should find this bestiality in the faces of the actors, as a symptom that emerges from (or beyond) their 
performances. Hervé Joubert-Laurencin's view of Anne Wiazemsky's face, for instance, deals with this matter: in his opinion, her luminous serenity is crossed by an ugly grimace, which suggests that her face is double, just like many other elements in the film ${ }^{\text {xxxiv }}$. We could extrapolate this idea to the fluctuation between coldness and bestial histrionics in the majority of performers. In these cases, the hidden pig emerges organically in their bodies when they act.

However, there are also real pigs in the film, and I would like to focus on them now, as I believe that they can help us to analyse the plastica facciale concept. These pigs are shut away in Mr. Klotz's pigsty, where Julian goes to fornicate. That is an image that appears in the film's title credits but it remains separate from the bourgeois spaces where the characters talk. Its possible meanings are multiple: for instance, according to some dialogues, pigs could be analysed as a metaphor for Jews in the Nazi camps. This hypothesis is interesting in a movie as polysemic as Porcile, but I will move away from it and instead focus on the pigsty as a place of hidden passions: it is a space that encapsulates the repressed bestiality of bourgeoisie, and not only Julian's sexual tendencies, but also the hidden pig behind the plastic surgery.

Considering that in the episode of the film set in the past the face of the cannibal is closely linked with the Sicilian landscape ("the face of landscape is echoed by the landscape of face" ${ }^{\text {xxxv }}$ ), we could say that the pigsty is the interior version of Herdhitze's face: both are made up of pig flesh which is industrially and symmetrically organised, either with rational compartments or through plastic surgery. Furthermore, they each are voracious images - both the swallowing close-up and the mass of pigs which eventually devour Julian. The comparison between the two images is very rich, and corresponds to the difference that Pasolini denoted between the two fascisms in his opinion articles: on the one hand, there was Mussolini's old fascism; on the other, the new fascism of the consumer society. He claimed that the old one imposed a homogenization which was eventually just formal, while the new one deeply influences the way people think and act, and causes them to be happy with this alienated situation ${ }^{\text {xxxvi }}$. Here, the pig isn't just a bourgeois or a leader, it is everyone. The Horst Wessel Lied, which we hear in the title credits in the pigsty, not only links the pigs with the old fascism, it also shows us what the face of the new fascism is: it's not one pig, or two or three, but a herd of them ${ }^{\text {xxxvii }}$. 
The plastica facciale on Herdhitze's face conceals not only the filth of the pigsty, but also its industrial processes. However, that's not the only image in the contemporary episode which is built upon it. Mr. Klotz's neoclassical villa in Godesberg is similar to the pigsty, in both its exterior and its interior spaces (Figure 2). All these places are shown with strong perspective lines organising a symmetrical space, just like in the pigsty: the characters walk next to an immense lake or along endless corridors and the camera moves like a compass, a ruler or a line, as Noel Purdon defined its movement ${ }^{\text {xxxviii }}$. The pigsty seems to be the primordial space of all the settings in the story, as if the plastic surgery had transformed them, and the entire film can be examined through the tension between the repressed wildness of the primordial pigsty and the aristocratic spaces that are built on it. That is what Naomi Greene called "the mannerist temptation" in Teorema, Porcile and Salò o le 120 giornate di Sodoma: a combination of fire and ice, burning passions repressed by an icy world ${ }^{\mathrm{xxxix}}$. Herdhitze's face and Mr. Klotz's villa are reformed pigsties, digestion spaces which hide their primordial wildness beneath a thick layer of make-up or with the help of plastic surgery. In fact, the real Godesberg is also a city that has been remade through historical digestion: Hitler signed his ultimatum to Czechoslovakia there, but after the Second World War it became a holiday destination for German businessmen ${ }^{\mathrm{xl}}$.

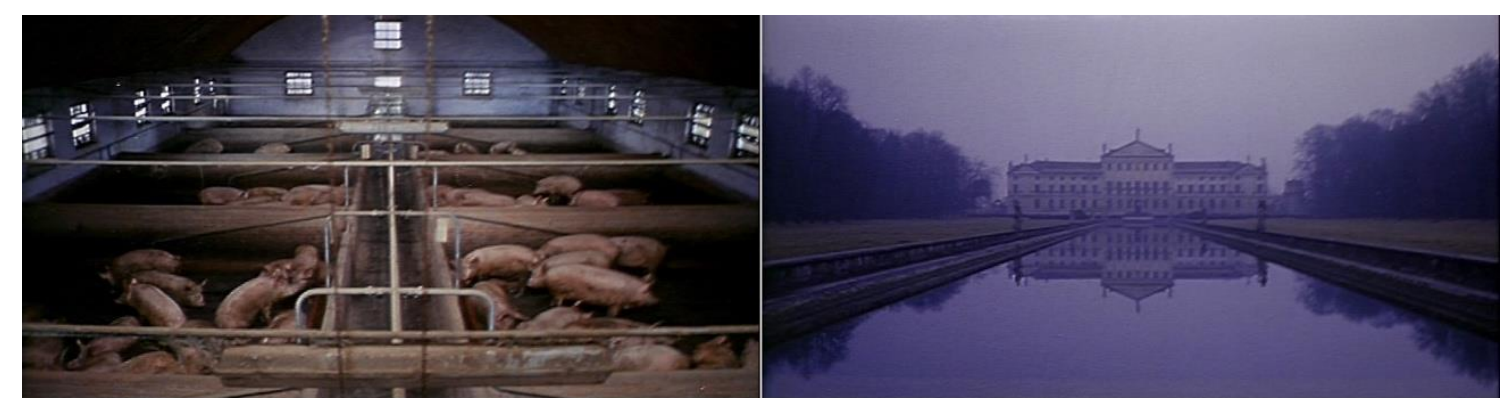

Figure 2

Finally, the plastica facciale can also be regarded by considering the rigidness of Herdhitze's expression by itself, without any need to resort to other images. Its stillness makes a great contrast with most of Pasolini's close-ups, as it isn't shaped by spontaneous gestures, instead it is immobile, and all drama has been erased from it. This idea brings us back to Grosz's pictures. In the introduction to the Spanish edition of The Face of the Ruling Class, Eduardo Subirats says that Grosz doesn't draw, he indicates, and his œuvre should not be placed within the tradition of caricature, but in the history of portraits. 
According to Subirats, the singularity of his portraits - compared to Rembrandt's or those from romanticism - is the lack of interiority underneath the surface: "through his pen the totality of soul that resides in the face as a plastic manifestation of person collapses. There's no person, no face, nor soul, any more. What Grosz paints is the degradation of the mask. Stereotyped gestures, muscular rigidness, coldness, cruelty in the lips, the turbid, empty gaze." xli To find George Grosz's legacy in Porcile, therefore, there's no need to look for the pigs beneath the plastica facciale. The style of the Berlin artist can be found in the plastica facciale itself, in its industrial and inhuman nature, in those talking heads which, according to Anna Gilardelli, have imposed the "expressible man" to replace Béla Balázs" “visible man”xlii.

This lack of interiority is also a strong idea in Pasolini's articles. In his famous "The glowworm article" ("L'articolo delle lucciole"), whose original title was "The power vacuum in Italy" ("Il vuoto del potere in Italia"), he says that the faces of Christian Democrat politicians seem smiling and sincere, but "In reality they are masks. I'm sure that, if we took away those masks, we wouldn't even find a pile of bones or ashes: there would be nothingness, a void"xliii. "Faceless power", an expression he had previously used in the title of another article ${ }^{x l i v}$, was for him another way to approach the consumerist society, where economic flows rule and politicians are just puppets. From this point of view, the process of historical digestion and the plastica facciale has been so strong that it has erased any kind of wildness, history or even humanity. Herdhitze's face has hidden his crimes so well that it has achieved an empty expression, and the swallowing close-up has finally become that of a mummy or a wax figure with nothing to say, just an executant or an executioner.

\section{Conclusions}

Like other movies of that time, such as Week End and La grande bouffe, Pier Paolo Pasolini's Porcile approaches consumption from a three-dimensional perspective: as a literal representation, as a metaphor for the consumer society and as an aesthetical dispositif to define the spectator's relationship to the movie. In line with these ideas, which are obvious from both the movie itself and from Pasolini's texts, I set out to analyse the form of the film from the point of view of consumption. As a result, we have found 
three aesthetic characteristics: the hungry gaze, the swallowing close-up and the plastica facciale, which correspond to three different stages in an organic nutritive process: hunger, consumption and digestion. I have analysed them separately, but they are closely linked, as they appear progressively: the main idea of the hungry gaze (editing as hunting) is the basis for the swallowing close-up, and the latter allows us to introduce the notion of plastica facciale. For this reason, I do not believe it is possible to understand one without the other, just like what happens with the real organic chain of hungerconsumption-digestion.

These three organic steps describe two different visual processes: the relation between images through editing and the relation between the spectator and the images. Firstly, while the links between characters in the plot of Porcile are defined by consumption, so are the connections between shots. Based on Pasolini's writings on cinema, certain studies on avant-garde art (particularly those by Georges Didi-Huberman and María Cunillera) and the actual images in Porcile, a film theory on voraciousness based on editing can be established. The hungry gaze and the swallowing close-up are visual characteristics in which shots, characters and other diegetic elements are related either through the desire for ingestion or effective consumption. In addition, these two characteristics, as well as plastica facciale, can also have historical and political implications. The hungry gaze is, in general, progressive, as it is seeking something new, and in fact the cannibals experience a kind of civilised development: the cannibal starts his progress alone, and then finally he is leader of a small community. On the contrary, the swallowing close-up is repressive; it is a synonym for the tyranny and violence of a character able to devour others; the plastica facciale is also reflexive and repressive, as it corresponds to the writing and construction of history.

Secondly, hunger, consumption and digestion define our relation with images as spectators. Hunger requires that a new image should appear, and thus it's open and centrifugal, while consumption closes off the meaning and gives us a centripetal image (just as Pasolini suggested in his comparison between editing and death). The third stage, digestion, is born out of the reflexion on a single shot, when we think about its implications in relation with other shots in the film (in this case, the pigsty) or other artistic fields (the drawings by George Grosz). These mechanisms shape an organic approach to spectator experience based on the idea of visual consumption. Pasolini's 
desire to make a film that would be impossible to consume arises here through the idea of time: the temporal dilatation of the episode set in the past is closely linked to visual hunger, desire and the wait for a new image in the vast, empty spaces of Sicily. Plastica facciale plays a similar role: because it dehumanises characters (as Eduardo Subirats pointed out regarding Grosz's drawings), it makes the visual consumption arid and dry.

My analysis has explored Pasolini's film theory, some studies on the avant-garde, the drawings of George Grosz and the film itself. For this reason, the resulting characteristics might seem to be simply intersections of these concepts and artistic works; the hungry gaze, the swallowing close-up and the plastica facciale seem restricted to this specific film through this specific analysis. However, while the three characteristics are born out of this analysis, I believe they have a wider validity, which goes beyond Porcile and even Pasolini's works. There are several examples we could mention: the hungry gaze is not only found in La ricotta or Appunti per un film sull'India (Pier Paolo Pasolini, 1968), where the filmmaker asks different people if they would play a man who sacrifices himself to a tiger, but also in certain Brazilian Cinema Novo films, such as Vidas Secas/Barren Lives (Nelson Pereira dos Santos, 1963) and Deus e o Diabo na Terra do Sol/Black God, White Devil (Glauber Rocha, 1964); the swallowing close-up is important, as we have seen, in the cinema of Marco Ferreri, but also in Aguirre, der Zorn Gottes/Aguirre, Wrath of God (Werner Herzog, 1972); meanwhile the plastica facciale can offer new insights into the final image of Week End, when the main character has become a cannibal.

These examples show how these characteristics can be transferred to other movies that also dealt with hunger or consumption processes in the sixties and seventies, but it's possible to go further. Hunger-consumption-digestion is a chain that can define a voracious approach to film language in general: the first image desires a second one and catches it, or the first image is devoured by the second one, which then digests it. The system could be useful to study other kinds of movies, even if they don't deal with consumption topics, such as genre films. For example, hunger/consumption can define human relationships in a melodrama, where characters metaphorically devour each other, but also the conflictive relation between 'human' and 'nature' in an adventure film, where the explorer wants to conquer a particular space but is menaced or devoured by it. In these cases, the alignment of the relation between images and the relation between the spectator 
and the images is obviously maintained, as we experience identification with the characters in the plot, and the concept of hunger/consumption expands its significance over films without any need to explicitly introduce notion of consumption.

Finally, this system can help to define the cinematic experience even if we forget about the content of images, plot or characters. Until now we have seen how film editing can define the hunger-consumption-digestion chain. Now we could say the opposite: that the hunger-consumption-digestion chain is what defines the visual functioning of film editing. A single image generates hunger, and the desire for a second one. When this second image appears, it erases and replaces the first one, as if it had swallowed the other. This second image will always possess the memory of the first, so it will assimilate it, digesting its previous content. And when the digestion is finished, this second image provokes hunger, so we desire a third one, and the process starts all over again. The process of hunger-consumption-digestion is like breathing, or systole-diastole alternation, which we experience in every movie we see, regardless of the topic. Cinema can be a voracious experience. It is made up of images, and each image devours the previous one, assimilating it, and provoking the desire for a new shot. It is a self-destructive chain where each shot eats the previous one, and everything is served up to us in a big screen that is laid out like a table.

\section{Acknowledgements:}

I would like to thank Fran Benavente, Xavier Pérez, Àngel Quintana and Alberto Ruiz de Samaniego for helpful comments and Michael Bunn for the revision of the text.

\footnotetext{
${ }^{\text {i }}$ Morando Morandini, 'El moralista apocalíptico: Ferreri en los años setenta y ochenta', in Esteve Riambau (ed), Antes del Apocalipsis: el cine de Marco Ferreri (Madrid and Valencia: Cátedra / Mostra del Cinema Mediterrani, 1990), p. 50.

ii David Oubiña, Filmología: ensayos con el cine (Buenos Aires: Manantial, 2000), p. 116.

iii Marie-Claire Ropars-Wuilleumier, 'Le cru et le cuit', Esprit, March 1968. Text included in Marie-Claire Ropars-Wuilleumier, L'Écran de la mémoire. Essais de lecture cinématographique (Paris: Éditions du Seuil, 1970), pp. 152-155.

iv Domènec Font, Michelangelo Antonioni (Madrid: Cátedra, 2003), p. 181.

v 'Destins du cannibalisme', Nouvelle Revue de Psychanalyse, vol. 6 (Autumn 1972).

${ }^{v i}$ Michel Boujut, 'L’homme physiologique', L'Avant-Scene Cinéma, vol. 548 (January 2006), p. 1.

vii Jean Duflot, Entretiens avec Pier Paolo Pasolini (Paris: Pierre Belfond, 1970), p. 58.

viii Nico Naldini, Pasolini: una vita. Edizione riveduta e ampliata con documenti inediti (Albaredo d'Adige: Tamellini, 2014), pp. 27-28.
} 
ix Pier Paolo Pasolini, 'La paura di essere mangiati', Tempo, vol. 30, ${ }^{\circ} 36$ (September $3^{\text {rd }}$, 1968), in Pier Paolo Pasolini and Gian Carlo Ferretti (ed), Il caos (Roma: l'Unità/Editori Riuniti, 1981).

${ }^{x}$ Hervé Joubert-Laurencin, Pasolini: portrait d’un poète en cinéaste (Paris: Cahiers du cinéma, 1995), p. 36. Marco Antonio Bazzocchi, I burattini filosofi: Pasolini dalla letteratura al cinema (Milan: Bruno Mondadori, 2007), p. 53.

xi Jean Duflot, Op. Cit., p. 95.

xii Jean-Michel Gardair, 'Il Porcile di Pasolini', Paragone, vol. 296 (October 1969). Cited in Naomi Greene, Pier Paolo Pasolini: Cinema as heresy (Princeton: Princeton University Press, 1990), p. 147.

xiii Mieke Bal, Reading "Rembrandt": beyond the word-image opposition (Cambridge: Cambridge University Press, 1991).

${ }^{\text {xiv }}$ Georges Didi-Huberman, La ressemblance informe, ou le gai savoir visuel selon Georges Bataille (Paris: Macula, 1995), pp. 67-74.

xv Pier Paolo Pasolini, 'Res sunt nomina', Bianco e nero, F. 3/4 (March-April 1971). Text included in Pier Paolo Pasolini, Empirismo eretico (Milan: Garzanti, 1995), p. 257-262.

xvi Pier Paolo Pasolini, Empirismo eretico (Milan: Garzanti, 1995), pp. 293-297.

xvii Marco Antonio Bazzocchi, Op. Cit., pp. 80-82.

xviii Naomi Greene, $O p$. Cit., pp. 146-147. Hervé Joubert-Laurencin, Op. Cit., p. 202. Anna Gilardelli, 'Il volto e l'allegoria: "Teorema" e "Porcile", Bianco e Nero, A. LXXII, F. 571 (September-December 2011), p. 9.

xix Michele Mancini and Giuseppe Perrella, Pierpaolo Pasolini: corpi e luoghi (Rome: Theorema, 1982), p. 487.

${ }^{x x}$ Pier Paolo Pasolini, 'Battute sul cinema', Cinema e Film, A. 1, n. 1 (Winter 1966-1967). Text included in Pier Paolo Pasolini, Empirismo eretico (Milan: Garzanti, 1995), pp. 227-236.

xxi Pier Paolo Pasolini, 'Osservazioni sul piano-sequenza' (1967), in Pier Paolo Pasolini, Empirismo eretico, (Milan: Garzanti, 1995), pp. 237-241.

xxii Duvaldo Bamonte, Afinidades eletivas: o dialogo de Glauber Rocha com Pier Paolo Pasolini (1970-

1975) (São Paulo: Universidade de São Paulo, 2002), pp. 66-67. Naomi Greene, Op. Cit., p. 157.

xxiii Sam Rohdie, The Passion of Pier Paolo Pasolini (Bloomington and London: Indiana University Press / British Film Institute, 1995), p. 41.

xxiv "forme spatiale de l'experiénce" (translated by the author), Georges Didi-Huberman, Op. Cit., pp. 8385.

xxv "nous fait écarquiller les yeux comme un petit poisson devant un gros, comme si nous allions être dévorés" (translated by the author), Ídem, p. 56.

xxvi Ídem, p. 58.

xxvii María Cunillera, Metáforas de la voracidad en el arte del siglo XX (Madrid: Universidad Complutense de Madrid, Facultad de Bellas Artes, 2010), p. 66.

xxviii Pascal Bonitzer, 'Le gros Plan', Revue belge du cinéma, vol. 10 (1984). Text included in Pascal Bonitzer, Peinture et cinéma: décadrages (Paris: Cahiers du cinéma / Éditions de l'Etoile, 1986), pp. 8791.

xxix Hervé Joubert-Laurencin, Salò ou les 120 journées de Sodome de Pier Paolo Pasolini (Paris: Les Éditions de la Transparence, 2012), p. 56.

${ }^{\mathrm{xxx}}$ George Grosz, Love above all and other drawings (New York: Dover, 1971), p. 79.

xxxi Henry Miller, 'Introduction', in George Grosz, Ecce homo (New York: Grove Press, 1966), p. xi.

xxxii George Grosz, Love above all and other drawings (New York: Dover, 1971), p. 116.

xxxiii George Grosz, "Circe”, Fine Arts Library, Fogg Art Museum, Harvard University.

xxxiv Hervé Joubert-Laurencin, Op. Cit. 1995, pp. 201-202.

xxxv "al volto del paesaggio fa eco il paesaggio del volto" (translated by the author), Anna Gilardelli, $O p$. Cit., p. 17.

xxxvi Pier Paolo Pasolini, 'Sfida ai dirigente della televisione', Corriere della sera, December $9^{\text {th }} 1973$. Text included with the title 'Acculturazione e acculturazione' in Pier Paolo Pasolini, Scritti corsari (Milan: Garzanti, 1992).

xxxvii The tension between the individual and the mass is already found in Grosz's works, as Daniel Lesmes González points out: 'Georges Grosz y los malos humos de Moloc', Anales de Historia del Arte, vol. 16 (2006), p. 354. Grosz also wrote about the alienated and animal condition of the masses: "Hitler served to confirm my old contempt for the masses as a herd of docile sheep directed by the will of their shepherd, with a perverted pleasure in choosing their own butcher", George Grosz, A Little Yes and a Big No: The Autobiography of George Grosz (New York: Dial Press, 1946), p. 318.

xxxviii Naomi Greene, Op. Cit., p. 142.

xxxix Ídem, p. 145.

xl Ídem, p. 139. 
xli "bajo su pluma se desmorona la totalidad del alma que habita en el rostro como manifestación plástica de la persona. Ya no hay persona, ni rostro, ni alma. Lo que pinta Grosz es la degradación de la máscara. Gestos estereotipados, rigidez muscular, frialdad, crueldad en los labios, la mirada turbia y vacía" (translated by the author), Eduardo Subirats Rüggeberg, 'Introducción a la edición castellana', in George Grosz, El rostro de la clase dominante \& iAjustaremos cuentas! (Barcelona: Gili, 1977), p. 15.

xlii Anna Gilardelli, Op. Cit., pp. 15-16.

xliii "In realtà essi sono appunto delle maschere. Son certo che, a sollevare quelle maschere, non si troverebbe nemmeno un mucchio d'ossa o di cenere: ci sarebbe il nulla, il vuoto" (translated by the author), Pier Paolo Pasolini, 'Il vuoto del potere in Italia', Corriere della sera, February $1^{\text {st }} 1975$. Text included with the title 'L'articolo delle lucciole' in Pier Paolo Pasolini, Scritti corsari (Milan: Garzanti, 1992).

xliv Pier Paolo Pasolini, 'Il potere senza volto', Corriere della sera, June $24^{\text {th }} 1974$. Text included with the title "Il vero fascismo e quindi il vero antifascismo' in Pier Paolo Pasolini, Scritti corsari (Milan: Garzanti, 1992). 